\title{
DIGITAL EFFECTS ON MACROECONOMIC STABILITY IN THE FRAMEWORK OF COVID-19 PANDEMIC: EU PRACTICE*
}

Yuliia Humenna

PhD (Economics), Senior lecturer

Sumy State University

Rymskogo-Korsakova st., 2, Sumy, Ukraine, 40007

e-mail: y.gumenna@finance.sumdu.edu.ua

ORCID: https://orcid.org/0000-0001-5309-6016

Scopus Author ID: 57223390447

Inna Tiutiunyk

Doctor of Economic Sciences, Associate Professor Sumy State University

Rymskogo-Korsakova st., 2, Sumy, Ukraine, 40007 e-mail: i.karpenko@finance.sumdu.edu.ua ORCID: https://orcid.org/0000-0001-5883-2940

Scopus Author ID: 57195070131

Oleksandra Tverezovska

student

Sumy State University

Rymskogo-Korsakova st., 2, Sumy, Ukraine, 40007 e-mail: o.tverezovska@finance.sumdu.edu.ua

ORCID: https://orcid.org/0000-0002-0054-5575

\begin{abstract}
The article deals with the investigation of the impact drivers on the gross domestic product as the main indicator of socio-economic development of the country in conditions of the COVID-19 pandemic. The subject of the research in the article is the indicators of macroeconomic stability of the EU and Non-UE countries. The purpose of the article is to assess interrelation between the GDP and destabilizing economic factors, for European Union and Non-EU countries, and - to define the role of digitalization in providing the country's economic growth. Tasks: to study the trends of indicators of macroeconomic stability of the country, to determine the role of digitalization in economic development, to conduct a comparative analysis of indicators of digitalization of the economy and macroeconomic stability of EU and Non-EU countries. General scientific used research methods: analysis - to analyze the main indicators of macroeconomic stability of countries and identify trends in their change under the influence of digitalization processes; methods of factor analysis - to find the factors that have the greatest impact on the indicators of macroeconomic stability of the country. The obtained results: the economic barriers affected by the pandemic were defined: dramatic falling of foreign direct investments; declining of cross-country trade volumes; global manufacturing output decreasing; unemployment rising, reductions in working time, temporary layoffs and job-search discouragement. Empirical estimations based on the correlation analysis allowed making the conclusions about: close inverse relationship between GDP, import, inflation rate; slight inverse relationship between GDP and FDI, unemployment rate, external debt, general governmental gross debt; little direct link between GDP and population, IMD World Digital Competitiveness rank.
\end{abstract}

Key words: economic growth, digitalization, COVID-19 pandemic, e-business, IMD World Digital Competitiveness rank, barrier, macroeconomic stability

Formulation of the problem. Today's trends show a significant impact of the COVID-19 on all spheres of country's socio-economic development. The processes of the global pandemic contributed to the intensification of digitalization of economy's sectors. Under these conditions, the volume of transactions in the field of e-business has increased that affected the development of both national and global economies.
The effects of the pandemic and the accompanying quarantine measures resulted in changes in lifestyle of the society, which ultimately affected the indicators of country's socio-economic development, including indicators of its macroeconomic stability and gross domestic product as the key one among them.

Analysis of recent research and publications. Investigations on the Covid-19 pandemic issues and its effects on the indicators of

Cite as: Humenna, Yu., Tiutiunyk, I., Tverezovska, O. (2021). Digital Effects on Macroeconomic Stability in the Framework of COVID-19 Pandemic: Eu Practice, The Journal of V. N. Karazin Kharkiv National University. Series: International Relations. Economics. Country Studies. Tourism. 13, 70-77. https://doi.org/10.26565/2310-9513-2021-13-07 
macroeconomic development, in particular within economic sectors, are gaining global popularity today among scientists and practicing financiers, entrepreneurs who already have active business or those who is at the stage of implementation the start-up.

The peculiarities of macroeconomic development, business digitalization and innovative digital trends for economic activity during the COVID-19 were covered in researches on economic, financial and social topics $[1,2,3,4,5,6]$. In particular, in our previous studies, the interrelation between the country's growth indicators, on the one hand, and crisis phenomena, levers of destabilization, on the other hand, was substantiated $[7,8,9,10,11]$.

Depending on the rates of economic, financial, social development of countries, each country has been more or less affected by the pandemic on its growth indicators. In order to improve visibility and objective research, it becomes necessary to conduct cross country analysis of the degree of impact of factors on the resulting indicator of economic growth - gross domestic product.

The purpose of the paper is to assess the sensitivity of GDP as the main indicator of socioeconomic development of both European Union (EU) and Non-EU countries to the instance of imbalances in the economy (the case of the COVID-19 pandemic) and substantiate the role of digitalization in providing the country's economic growth.

Research results. Nowadays among the main trends in the development of informatization of society, which applies to almost all spheres of life, including economics, public administration, science, art, it should be noted the intensive spread of digital processes, in particular rapid development of the Internet. Industries directly related to information and telecommunications technologies are growing faster than traditional industries and are gaining dominance. Such branches of economy as communication, mass media, consulting services, etc. gradually and organically flow into the sphere of the Internet.

Today, online transactions within digital platforms become increasingly important. Its development is so rapid that most of the world's largest companies, along with the traditional offline are beginning online business.

E-business is developing rapidly in the world, due to both the improvement of technical conditions and the peculiarities of consumer behavior. The COVID-19 pandemic further emphasized the role and importance of ICTs, intensifying the volume and scale of financial transactions online. Talking within global merits more than 205 countries are affected currently with the influence of COVID-19 [1, 2, 5]. The COVID-19 pandemic effects much the development of all areas, but it is especially important for the e-commerce activity, as this area allows ensure all necessary requirements of current coexistence, ensuring social distance. Ecommerce allows many businesses to operate in new conditions and expand the geography of its activity.

The downside of the pandemic medal considers its negative impact on the economic growth of the EU countries as well as Non-EU countries (Figure 1). As a result of the significant impact of the pandemic and the quarantine measures that accompanied it on the life of society, the following processes have become typical for all countries: dramatic falling of foreign direct investments; declining of cross-country trade volumes, in particular its export and import volumes; global manufacturing output decreasing; rising unemployment, reductions in working time, temporary layoffs and job-search discouragement [6].

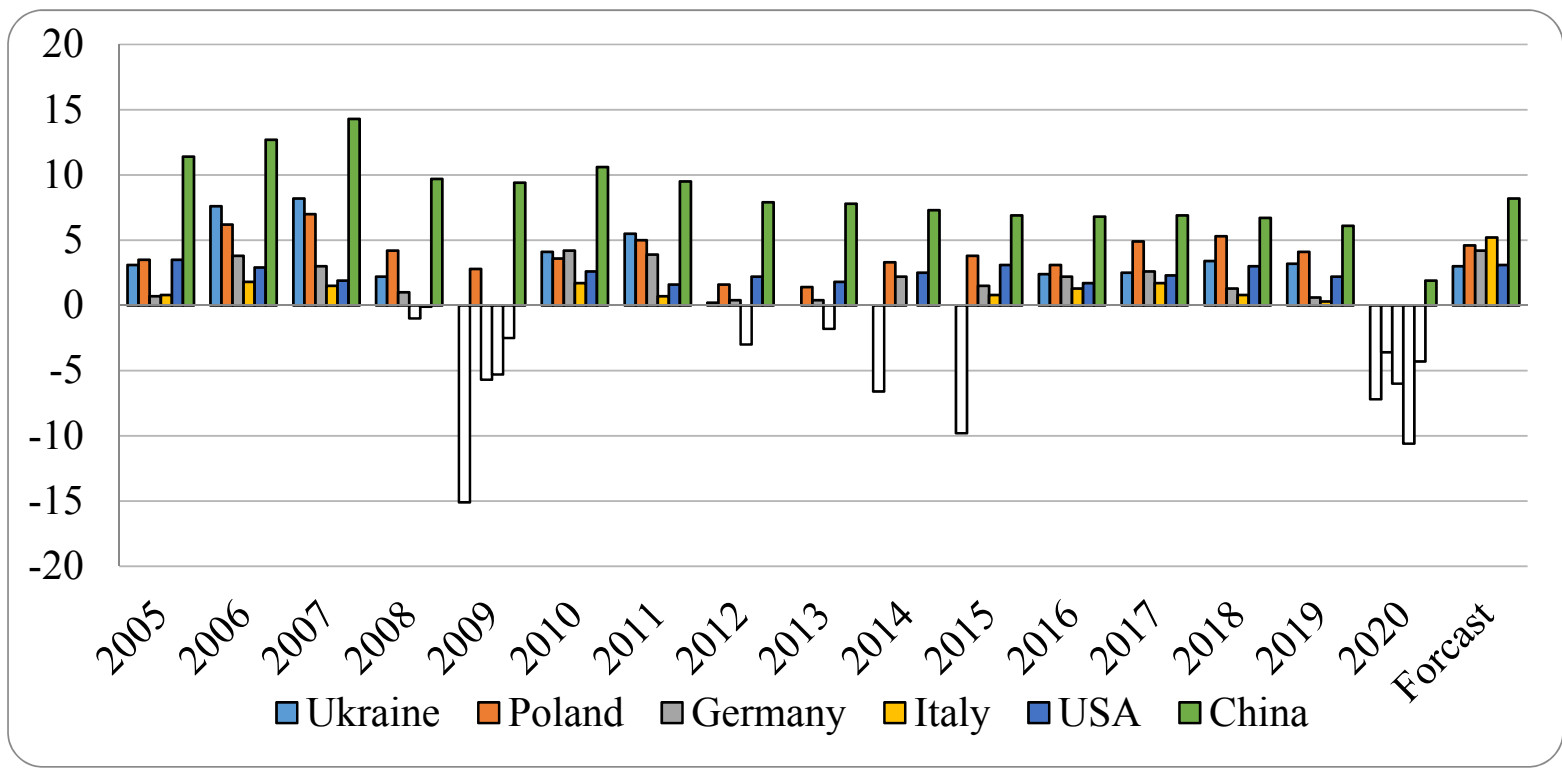

Figure 1. Dynamics of real GDP growth in the EU countries and Non-EU countries Source: created by the author based on the sources [11] 
The Figure 1 demonstrates that crisis situation caused by pandemic condition effects world economy even deeper than during the crisis in 2009 year. A Coronavirus crisis affects dramatically economies of EU countries as well as Non-EU countries. At the range of analyzed countries the worst results in 2020 year have Italy and Mexico - real GDP decreases here on 8,9\% and on $8,2 \%$ relatively. But according to forecast the situation will change for better and the rate of GDP growth in all analyzed countries will be positive.

Thus, the influence of Covid-19 pandemic has shifted the emphasis, role and importance of key indicators of GDP as the main macroeconomic indicator of country's economic development. In such conditions, there is a need to determine the degree of impact of key levers on GDP for EU countries and Non-EU countries.

It should be emphasized that the choice of factors that determine the GDP considering digital signs of current economic process is a difficult challenge. All traditional factors of GDP (macroeconomic indicators), except e-business and e-commerce transactions, are characterized by traditional measurement indicators. Due to the impossibility of accurately determining the volume of e-commerce and imperfect mechanisms of legal regulation this type of commerce, in particular its tax accruals and deductions, it is necessary to choose the indicator that reflects digital progress of the country and could be assessed. To our mind, the indicator that meets these criteria is IMD World Digital Competitiveness rate. It characterizes digital advantages of the country for digitally based economic activity. Moreover, IMD
World Digital Competitiveness rate represents opportunities and capabilities for the implementation of online forms of business at the macro level of the country. Thus, the factors of this index - technology, future readiness and knowledge - are relevant with characteristics of ecommerce as a form (component) of e-business. The factor "Technology" characterizes the ICT coverage of relevant economic entities. Factor "Knowledge" - characterizes the ability to use modern digital technologies, in particular the ability to work in online platforms while carrying out e-commerce. Factor "Future readiness" defines the forms and vectors for the implementation of the business model in the Internet environment (Table 1).

At the same time, for Ukraine, like many other non-EU countries, the active digitalization of all sectors of the economy and not only caused by COVID - 19 has become a certain kind of challenge.

Active role of digitalization processes and growth of online business during the pandemic period creates a need to make an observe on the IMD World digital competitiveness ranking 2020 (within its components - Knowledge, Technology and Future Readiness) in comparison with countries, which were taking into account in the analysis of the GDP level (Figure 2).

The position of Ukraine on the Figure 2 confirms the fact of low level of its digital competitiveness - thus, all three factors leave behind our country in a range of other analyzed countries in World rank. The worst positions of Ukraine in this ranking are followed by the factor Technology and Future readiness.

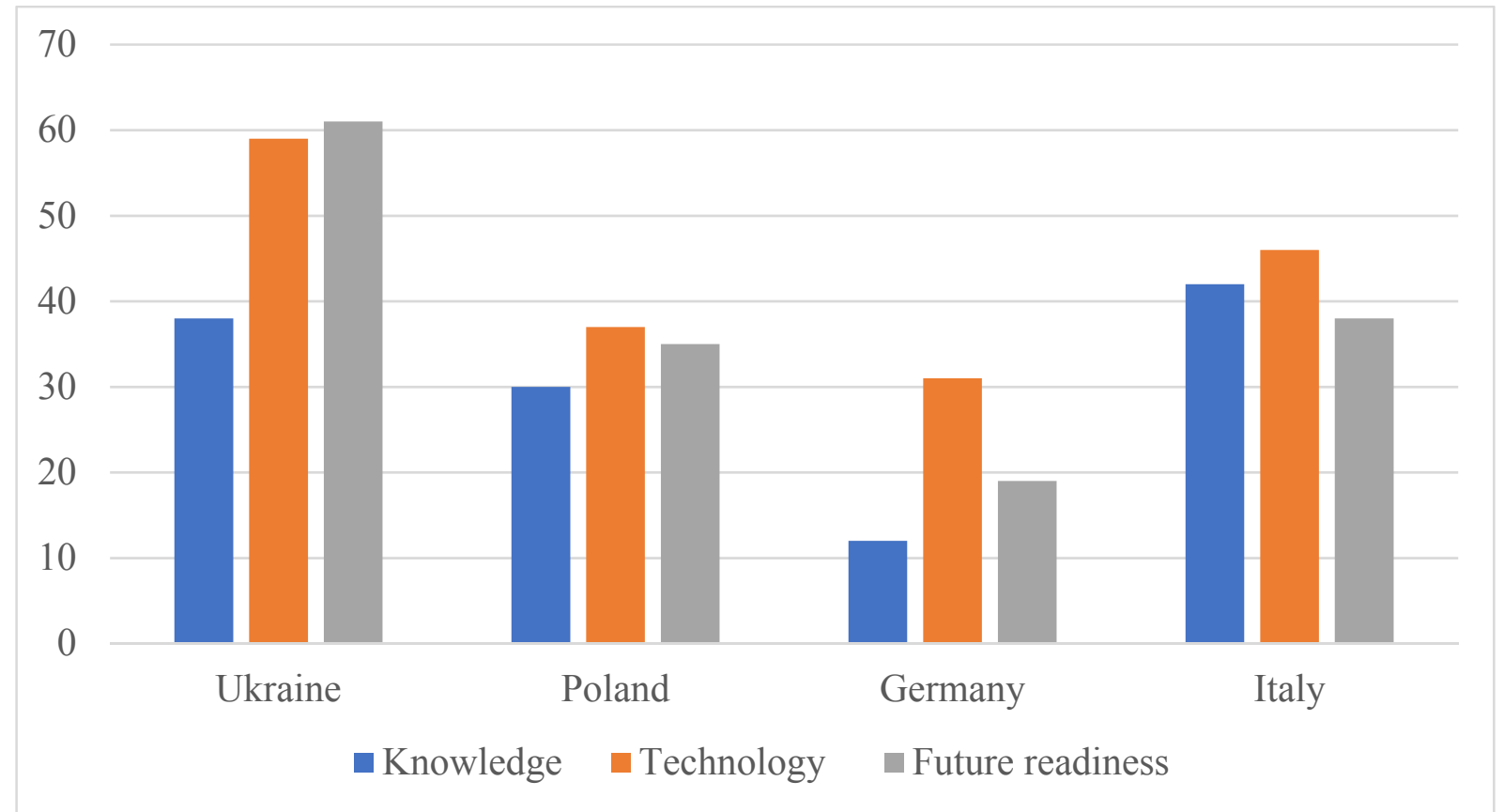

Figure 2. Countries ranking according to the factors of IMD World digital competitiveness ranking 2020 Source: created by the author based on the sources [12]. 


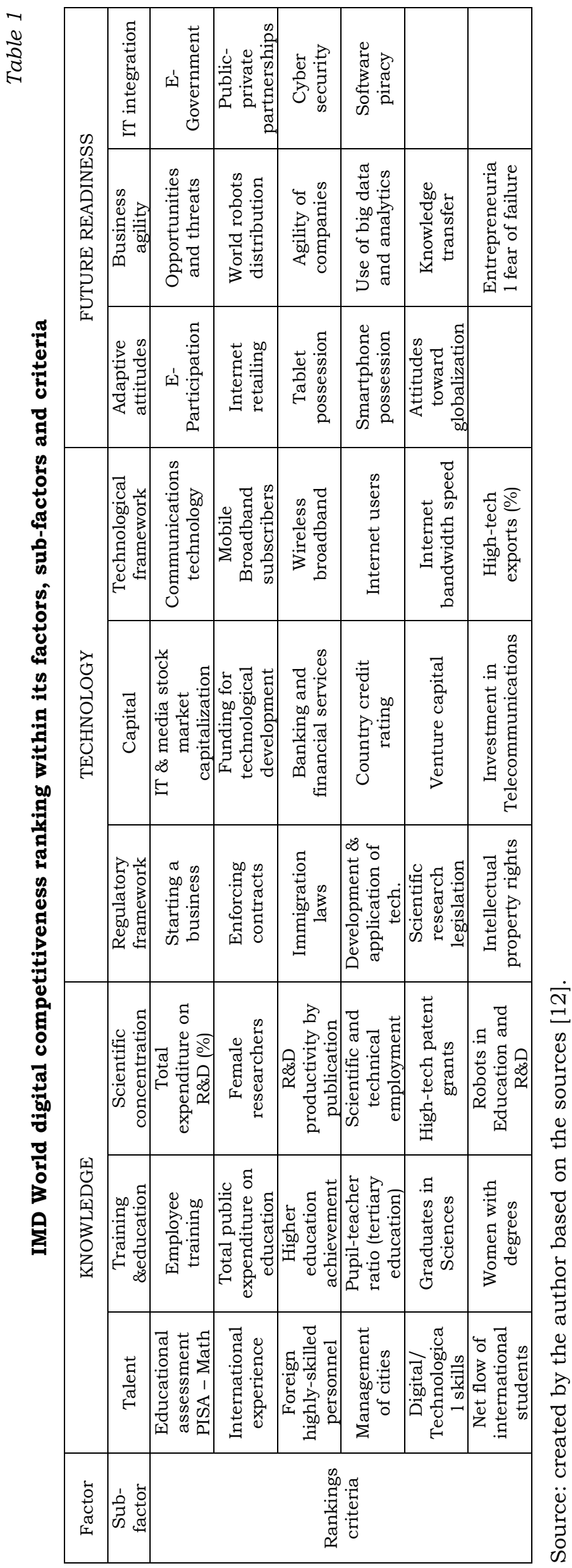


In order to conduct a more in-depth analysis of Ukraine's position in terms of digital competitiveness compared to other countries, the factors, sub-factors and criteria defining IMD World digital competitiveness ranking are systematized in the Table 3 . Each group of factors can be subdivided into sub-factors and each subfactor is measured by relevant criteria. Thus, according to the report of IMD World Competitiveness Center about IMD World digital competitiveness ranking 2020 in terms of 63 countries Ukraine has the best positions among the countries according on the factor Knowledge, in particular its two sub-factors: Training \& education sub factor (within the criteria - Total public expenditure on education and Pupilteacher ratio (tertiary education)) and Scientific concentration (within criteria Female researchers and $\mathrm{R} \& \mathrm{D}$ productivity by publication). The rating of Ukraine is completely opposite for two other factors - Technology and Future readiness. The country is characterized by five criteria in which its performance is the worst compared to other countries. They are: Scientific research legislation and Intellectual property rights (within the subfactor Regulatory framework in Technology aspect), Mobile Broadband subscribers and Wireless broadband (within the Technological framework in Technology aspect), Cybersecurity (IT integration in Future Readiness).

Therefore, as the factors of the proposal, which have a fundamental impact on the GDP, we can distinguish the following:

- export activity;

- import activity;

- foreign direct investment;

- inflation rate;

- unemployment rate;

- the size of national and external debt;

- IMD World Digital Competitiveness rate;

- population.

Therefore, in order to predict and regulate the size of GDP for EU countries and Non-EU countries in the conditions of instability, in particular - due to the COVID-19 pandemic, there is a need to manage mentioned above factors and define the role of digital competitiveness plays in GDP growth nowadays.

In order to specify the relationship between the GDP and the factors of its growth the method of Pairwise correlations of variables was carried out. The empirical estimates consider using World Bank Data for the period from 2013 till 2019 year. Factor model of GDP dependence on its growth indicators for Ukraine is presented in Table 2.

Table 2

Factor model of GDP dependence on its growth indicators for Ukraine

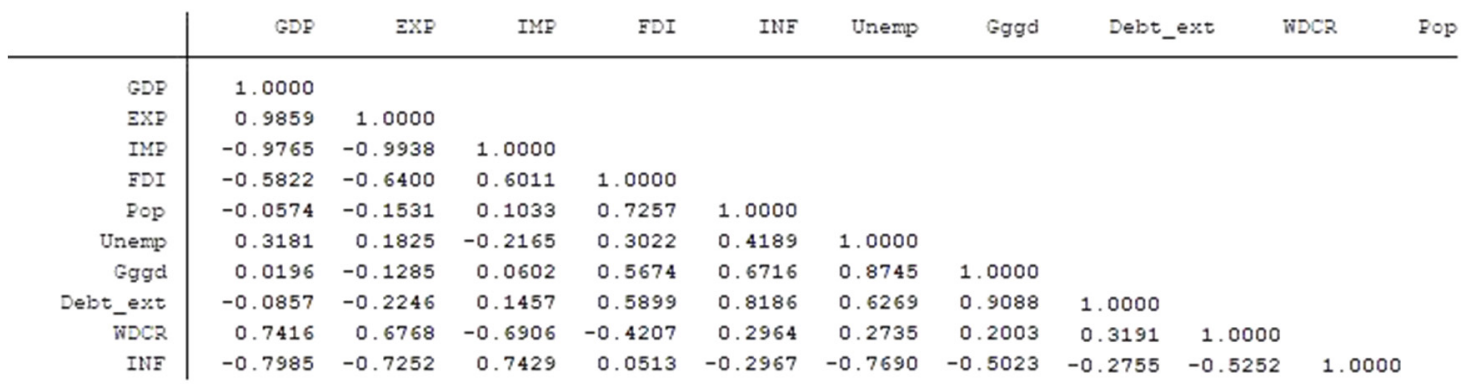

Source: created by the author based on the sources [11].

The standard built-in features of MS Excel have identified the following indicators, which proved the existence of a correlation between the factors of the econometric model, and identified the need of lag using for further results (Table 3).

Table 3

The correlation coefficients of GDP and its growth indicators for EU and Non-EU countries

\begin{tabular}{|c|c|c|c|c|c|c|c|c|c|}
\hline & 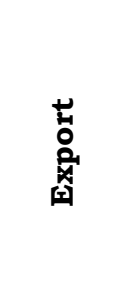 & $\begin{array}{l}\text { 亗 } \\
\text { 员 } \\
\text { g }\end{array}$ & 量 & 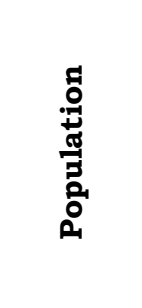 & 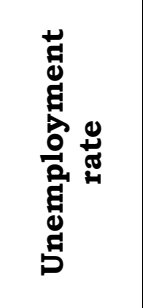 & 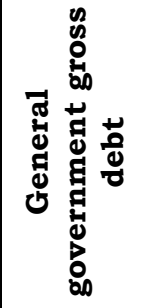 & 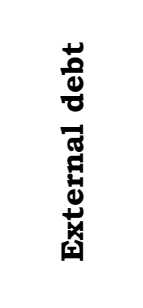 & 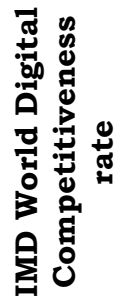 & 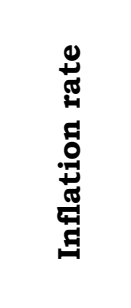 \\
\hline GDPUkraine & 0,9859 & $-0,9765$ & $-0,5822$ & $-0,0574$ & 0,3181 & 0,0196 & $-0,0857$ & 0,7416 & $-0,7985$ \\
\hline GDPPoland & 0,8154 & $-0,8215$ & $-0,5486$ & $-0,0639$ & $-0,4182$ & $-0,3788$ & $-0,4942$ & 0,2014 & $-0,8112$ \\
\hline GDPGermany & 0,7151 & $-0,7135$ & $-0,4261$ & $-0,0109$ & $-0,3910$ & $-0,4711$ & $-0,5322$ & 0,2374 & $-0,7109$ \\
\hline
\end{tabular}




\begin{tabular}{|c|c|c|c|c|c|c|c|c|c|}
\hline & $\begin{array}{l}\text { 范 } \\
\text { 品 } \\
\text { 䍃 }\end{array}$ & 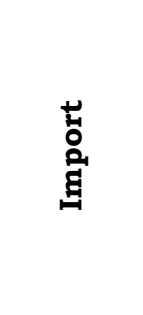 & 宫 & 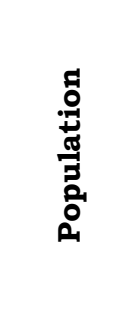 & 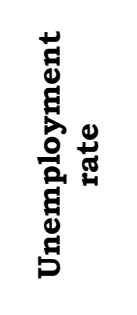 & 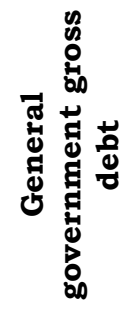 & 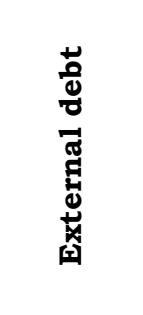 & 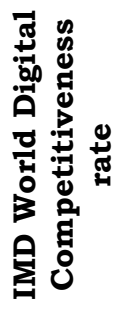 & 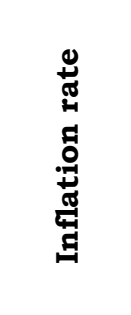 \\
\hline GDPItaly & 0,7091 & $-0,6612$ & $-0,6112$ & $-0,0813$ & $-0,7123$ & $-0,4424$ & $-0,4735$ & 0,3209 & $-0,7231$ \\
\hline GDPChile & 0,5109 & $-0,7372$ & $-0,4124$ & $-0,0412$ & $-0,5412$ & $-0,5423$ & $-0,4112$ & 0,7161 & $-0,8089$ \\
\hline GDPMexico & 0,4911 & $-0,7621$ & $-0,7145$ & $-0,0611$ & $-0,4709$ & $-0,4721$ & $-0,3991$ & 0,5981 & $-0,6093$ \\
\hline
\end{tabular}

Source: created by the author based on own calculation

Based on the calculations, the following conclusions are made:

- there is a close inverse relationship between the size of GDP and such indicators as the import activities, and inflation rate - that is, when number of above-mentioned factors increases, the amount of GDP decreases;

- there is a slight inverse relationship between the GDP and FDI, amount of population, unemployment rate, external debt; general governmental gross debt;

- there is little direct link between the amount of GDP and amount of population, level of IMD World Digital Competitiveness rank.

The results of the performed correlation analysis show that countries such as Ukraine, Mexico, Chile are characterized by a significant positive relationship between the IMD World Digital Competitiveness rate and GDP growth (respectively - 0.74, 0.6, 0.72), while Poland, Germany, Italy (respectively - 0.20, 0.24, 0.32) - are characterized by an insignificant relationship between the level of digitalization of the country and the growth of its GDP.

Such results can be explained by the fact that the level of digitalization in the EU countries was higher even before the emergence of COVID-19 digital forms of doing business have been practiced for a long time and are being successfully implemented - therefore, the business entities were readier to practice online methods in work during quarantine period accompanied by COVID - 19.

Conclusions. The unstable socio-economic situation in the countries of the world, which has developed over the last year as a result of the COVID-19 pandemic, is characterized by a global scale of coverage and the long-term nature of the impact on society and economic development. At the same time, the pandemic and the accompanying quarantine measures led to the intensification of digitalization processes and the active introduction of an online business. New models and forms of doing business, redistribution of consumer interests, and consequently the active development of some sectors of the economy and the decline of others all this has led to a shift in emphasis on the role and leverage of gross domestic product as an indicator of socio-economic development.

The results of the investigation based on empirical estimates allowed to make following conclusions: there is a close inverse relationship between the size of GDP and such indicators as the export activities, FDI, general governmental gross debt and external debt; there is a slight inverse relationship between the GDP and inflation rate; there is little direct link between the amount of GDP and amount of population; there is a direct close relationship between amount of GDP and level of e-commerce, which we identify as ranking in IMD World Digital Competitiveness rank.

\section{ЕФЕКТИ ВПАИВУ ЦИФРОВІЗАЦІї НА МАКРОЕКОНОМІЧНУ СТАБІАЬНІСТЬ В УМОВАХ ПАНДЕМІї COVID-19: ПРАКТИКА СС}

Гуменна Юлія Григорівна, кандидат економічних наук, доцент, старший викладач, кафедра фінансів і підприємництва, Сумський державний університет, вум. Римського-Корсакова, 2, м. Суми, 40007, Україна, E-mail: y.gumenna@finance.sumdu.edu.ua, ORCID: https://orcid.org/0000-0001-5309-6016, Scopus Author ID: 57223390447

Тютюник Інна Вомодимирівна, доктор економічних наук, доцент, доцент, кафедра фінансів $\mathrm{i}$ підприємництва, Сумський державний університет, вул. Римського-Корсакова, 2, м. Суми, 40007, Україна E -mail: i.karpenko@finance.sumdu.edu.ua, ORCID: https://orcid.org/0000-0001-5883-2940, Scopus Author ID: 57195070131

Тверезовська Охександра Ігорівна, студентка, кафедра фінансів і підприємництва, Сумський державний університет, вул. Римського-Корсакова, 2, м. Суми, 40007, Україна E-mail: o.tverezovska@finance.sumdu.edu.ua, ORCID: https://orcid.org/0000-0002-0054-5575 
Стаття присвячена дослідженню факторів впливу на валовий внутрішній продукт як основний індикатор соціально-економічного розвитку країни в умовах пандемії COVID-19. Предметом дослідження у статті є показники макроекономічної стабільності країн Європейського Союзу та країн, що не входять в ЄС. Мета статті - оцінити взаємозв'язок між ВВП і дестабілізуючими економічними факторами для країн Європейського Союзу та країн, що не входять в ЄС, i - визначити роль цифровізації в забезпеченні економічного зростання країни. Завдання: дослідити тенденції зміни показників макроекономічної стабільності країни, визначити роль цифровізації в економічному розвитку, провести порівняльний аналіз показників цифровізації економіки та макроекономічної стабільності країн ЄС та країн, що не входять до ЄС. Використовуються загальнонаукові методи дослідження: аналізу - для визначення основних показників макроекономічної стабільності країн та виявлення тенденцій іх зміни під впливом процесів цифровізації; методи факторного аналізу - для виявлення драйверів, які найбільше впливають на показники макроекономічної стабільності країни. Отримані результати: визначено економічні бар'єри, якими супроводжувалась пандемія: різке зниження обсягів прямих іноземних інвестицій; зниження обсягів міждержавної торгівлі; скорочення обсягів виробництва в глобальному вимірі; зростання безробіття, скорочення робочого часу, тимчасові звільнення і відмова від пошуку роботи. Емпіричні оцінки, розраховані на основі кореляційного аналізу, дозволили зробити висновки про: тісній зворотний зв'язок між ВВП, імпортом, рівнем інфмяції; невелику зворотну залежність між ВВП і ПІІ, рівнем безробіття, зовнішнім боргом, загальним державним валовим боргом; слабкий прямий зв'язок між ВВП і населенням, Світовим рейтингом цифрової конкурентоспроможності.

К^ючові слова: економічне зростання, цифровізація, пандемія COVID-19, електронний бізнес, Світовий рейтинг цифрової конкурентоспроможності, бар'єр, макроекономічна стабільність.

\section{ЭФФЕКТЫ ВАИЯНИЯ ЦИФРОВИЗАЦИИ НА ЭКОНОМИЧЕСКИЙ РОСТ В УСАОВИЯХ ПАНДЕМИИ COVID-19: ПРАКТИКА ЕС}

Гуменная Юмия Григорьевна, кандидат экономических наук, доцент, Сумский государственный университет, ул. Римского-Корсакова, 2, г. Сумы, 40007, Украина; е-mail: y.gumenna@finance.sumdu.edu.ua, ORCID: https://orcid.org/0000-0001-5309-6016, Scopus Author ID: 57223390447

Тютюнык Инна ВАадимировна, доктор экономических наук, доцент, Сумский государственный университет, ул. Римского-Корсакова, 2, г. Сумы, 40007, Украина; е-mail: i.karpenko@finance.sumdu.edu.ua, ORCID: https://orcid.org/0000-0001-5883-2940, Scopus Author ID: 57195070131

Тверезовская А^ександра Игоревна, студентка, Сумский государственный университет, ум. РимскогоКорсакова, 2, г. Сумы, 40007, Украина; e-mail: o.tverezovska@finance.sumdu.edu.ua, ORCID: https://orcid.org/0000-0002-0054-5575

Статья посвящена исследованию факторов воздействия на валовой внутренний продукт как основной индикатор социально-экономического развития страны в условиях пандемии COVID-19. Предметом исследования в статье являются показатели макроэкономической стабильности стран ЕС и стран, не входящих в ЕС. Цель статьи - оценить взаимосвязь между ВВП и дестабилизирующими экономическими факторами для стран Европейского Союза и стран, не входящих в ЕС, и - определить роль цифровизации в обеспечении экономического роста страны. Задачи: изучить тенденции изменения показателей макроэкономической стабильности страны, определить роль цифровизации в экономическом развитии страны, провести сравнительный анализ показателей цифровизации экономики и макроэкономической стабильности стран ЕС и стран, не входящих в ЕС. Используемые общенаучные методы исследования: анализа - для анализа основных показателей макроэкономической стабильности стран и выявления тенденций их изменения под влиянием процессов цифровизации; методы факторного анализа - для идентификации драйвером, оказывающие наибольшее влияние на показатели макроэкономической стабильности страны. Полученные результаты: определены экономические барьеры, сопровождающие пандемию: резкое падение объёма прямых иностранных инвестиций; снижение объемов межгосударственной торгов и; сокращение объёмов производства в глобальном контексте; рост безработицы, сокращение рабочего времени, временные увольнения и отказ от поиска работы. Эмпирические оценки, произведенные на основании корреляционного анализа, позволили сделать выводы о: тесной обратной связи между ВВП, импортом, уровнем инфмяции; небольшой обратной зависимости между ВВП и ПИИ, уровнем безработицы, внешним долгом, общим государственным валовым долгом; слабой прямой связи между ВВП и населением, Мировым рейтингом цифровой конкурентоспособности.

КАючевые смова: экономический рост, цифровизация, пандемия COVID-19, эмектронный бизнес, Мировой рейтинг цифровой конкурентоспособности, барьер, макроэкономическая стабильность.

\section{Мітература}

1. Andrienko, O. E-commerce and Consumer Trends During Coronavirus. URL: https://www.semrush.com/blog/ecommerce-covid-19/ 
2. Bhatti, A., Akram, H., Basit, H.M., Khan, A. U., Naqvi, S. M. R., Bilal, M. E-commerce trends during COVID-19 Pandemic. International Journal of Future Generation Communication and Networking. 2020, 13(2), 1449-1452.

3. Gao, X., Shi, X., Guo, H., Liu, Y. To buy or not buy food online: The impact of the COVID-19 epidemic on the adoption of e-commerce in China. PLoS ONE. 2020, 15(8). URL: https://journals.plos.org/plosone/article?id=10.1371/journal.pone.0237900

4. Pantelimon, F.-V., Georgescu, T. M., Posedaru, B.-S. The Impact of Mobile e-Commerce on GDP: A Comparative Analysis between Romania and Germany and how Covid-19 Influences the e-Commerce Activity Worldwide. Informatica Economica. 2020, 24(2), 27-41.

5. Nakhate, S. B., Jain, N. The Effect of Coronavirus on E-Commerce. Studies in Indian Place Names. 2020, 40(68), 516-518.

6. UNCTAD (2020). Covid-19 and E-commerce. Impact on businesses and policy responses. Retrieved URL: https://unctad.org/system/files/official-document/dtlstict2020d12_en.pdf

7. Tiutiunyk, I., Zolkover, A., Lyeonov, S., Kwilinski, A., Vysochyna, A., Kostornova, S. The Innovative financial technologies and its impact on shadow transactions. Socio-Economic Challenges. Proceedings of the International Scientific and Practical Conference. 2020, 422-425.

8. Humenna, Y. H., Tymoshenko, S. Merits and challenges of digital economy in developing countries. Proceedings from the International Scientific and Practical Conference on Socio-Economic Challenges. 2020, 436-439.

9. Tiutiunyk, I. V., Humenna, Yu. G. Financing of eco-oriented Projects: theory and practice. Managing economic growth: marketing, management, and innovations. Prague: Prague Institute for Qualification Enhancement. 2016, 428-440.

10. Боронос, В. Г., Карпенко, І. В. Моделювання макроекономічних індикаторів розвитку регіонів: оцінка рейтингу. Збірник тез доповідей 11-ї Всеукраїнської науково-практичної конференції "Статистична оцінка соціально-економічного розвитку" 2011, 143-146

11. International Monetary Fund. URL: https://www.imf.org/

12. IMD World Digital Competitiveness Ranking 2020. URL: IMD World Digital Competitiveness Ranking 2020

\section{References}

1. Andrienko, O. (2020). E-commerce and Consumer Trends During Coronavirus. URL: https://ww.semrush.com/blog/ecommerce-covid-19/;

2. Bhatti, A., Akram, H., Basit, H.M., Khan, A. U., Naqvi, S. M. R., Bilal, M. (2020). E-commerce trends during COVID-19 Pandemic. International Journal of Future Generation Communication and Networking, 13(2), 1449-1452.

3. Gao, X., Shi, X., Guo, H., Liu, Y. (2020). To buy or not buy food online: The impact of the COVID-19 epidemic on the adoption of e-commerce in China. PLoS ONE, 15(8). URL: https://journals.plos.org/plosone/article?id=10.1371/journal.pone.0237900

4. Pantelimon, F.-V., Georgescu, T. M., Posedaru, B.-S. (2020). The Impact of Mobile e-Commerce on GDP: A Comparative Analysis between Romania and Germany and how Covid-19 Influences the e-Commerce Activity Worldwide. Informatica Economica, 24 (2), 27-41.

5. Nakhate, S. B., Jain, N. (2020). The Effect of Coronavirus on E-Commerce. Studies in Indian Place Names, 40(68), 516-518.

6. UNCTAD (2020). Covid-19 and E-commerce. Impact on businesses and policy responses. URL: https://unctad.org/system/files/official-document/dtlstict2020d12_en.pdf

7. Tiutiunyk, I., Zolkover, A., Lyeonov, S., Kwilinski, A., Vysochyna, A., Kostornova, S. (2020). The Innovative financial technologies and its impact on shadow transactions. Socio-Economic Challenges. Proceedings of the International Scientific and Practical Conference, 422-425.

8. Humenna, Y. H., Tymoshenko, S. (2020). Merits and challenges of digital economy in developing countries. Proceedings from the International Scientific and Practical Conference on Socio-Economic Challenges, 436-439.

9. Tiutiunyk, I. V., Humenna, Yu. G. (2016). Financing of eco-oriented Projects: theory and practice. Managing economic growth: marketing, management, and innovations. Prague: Prague Institute for Qualification Enhancement, 428-440.

10. Boronos, V. G., Karpenko, I. V. (2011). Modeliuvannia makroekonomichnykh indykatoriv rozvytku rehioniv: otsinka reitynhu [Modeling of macroeconomic indicators of regional development: rating assessment]. Statistical assessment of socio-economic development: a collection of abstracts of the 11th All-Ukrainian scientific-practical conference, Khmelnytsky: Khmelnytsky University of Management and Law, 143-146

11. International Monetary Fund. URL:: https://www.imf.org/

12. IMD World Digital Competitiveness Ranking 2020. URL: IMD World Digital Competitiveness Ranking 2020

Статтю отримано 2 травня 2021 р. 